\title{
Flood Hazard Assessment in Agricultural Areas: The Case of the District of Pélébina in the Municipality of Djougou, Bénin
}

\author{
Luc O. Sintondji \\ National Water Institute, Laboratory of Hydraulics and Water Control, \\ University of Abomey-Calavi, Cotonou, Benin \\ Elliott R. Dossou-Yovo \\ Africa Rice Center, Bouaké, Côte d'Ivoire \\ Donald Akogou \\ Euloge K. Agbossou \\ National Water Institute, Laboratory of Hydraulics and Water Control, \\ University of Abomey-Calavi, Cotonou, Benin
}

Doi: 10.19044/esj.2017.v13n32p235 URL:http://dx.doi.org/10.19044/esj.2017.v13n32p235

\begin{abstract}
Flood is a natural disaster and causes loss of life and property destruction. Its impacts are large on agriculture especially in West African countries where smallholder farmers account for $80 \%$ of all the farms. The objective of this study was to assess flood risks in the inland valley of Dosir located in the district of Pélébina, northern Benin. Rainfall, discharge and water level in the riverbed were monitored using rain gauge, acoustic current meter and pressure sensors, respectively. The hydrological functioning of the inland valley was simulated using the Integrated Flood Analysis System (IFAS) model. The calibration was done based on the land use map (GlobalMap) and the soil water holding capacity map (UNEP). Our study demonstrated the existence of a high flood hazard in the inland valley of Dosir which reacts very quickly to rainfall solicitations. The IFAS model has shown a good performance in simulating the runoff in the riverbed of the inland valley with a coefficient of determination of 0.65 . The IFAS model can be used to design a flood management system in the district of Pelebina. Further studies are needed to assess the exposure and vulnerability of farmers to flood risk.
\end{abstract}

Keywords: Flood hazard, inland valleys, IFAS, discharge 


\section{Introduction}

West Africa alone possesses an overall area of arable inland valleys estimated to 20 millions of hectares. According to Africa Rice Center (2010), 2 million hectares of those inland valleys are used to grow rice. With an estimated rice yield of $3 \mathrm{t} / \mathrm{ha}$, production in West Africa would suffice to provide to the needs of the sub region. This demonstrates the great potential of inland valleys ecosystems for a substantial increase in the productivity of rice and vegetables as well as the expansion of areas under cultivation and for crops diversification. Thus, they would contribute to meeting the food and nutrient needs of an increasing population of more than 316 million inhabitants that is expected to reach 396 million by 2025 (SWAC/OCDE, 2013). Nonetheless, a reduced proportion of West African inland valleys are really cultivated. For instance, in Benin, only $4 \%$ of the total area of inland valleys estimated to 322,000 ha are exploited (Africa Rice Center, 2010). Happily, a growing interest is given to a larger and more efficient use of inland valleys and flood plains as noticed by Adams (1993). This interest focuses mainly on the increase of rice production (Windmeijer \& Andriesse, 1993). Erenstein (2006) goes further presenting inland valleys as a solution in a context where increasing both rice production and productivity is a priority in the sub-region. As a result, investments in the development of inland valleys and irrigation carry high expectations. Moreover, since the beginning of the climatic degradation (late 70s), agricultural policies of many countries in the sub-region stress on the development of inland valleys because of their key role in securing agricultural production (Dembélé, 2010).

As we intend to address the hydrological functioning of inland valleys, we need to examine the trends in the climate of West Africa. The climate in sub-Saharan West Africa has widely varied during recent decades compared to other regions. This important natural variability as well as the perspectives of an acceleration of anthropogenic climate change put at serious risk the possibility of a sustainable development in West African countries where agriculture represents $80 \%$ of the economy (Judex et al., 2009). Benin in particular is highly vulnerable to climate change (Nicholls, 1995). Agossou et al. (2012) in a study conducted in central and southern Benin enumerate delays in the beginning of rains, drought spells within rainy seasons as well as extreme rains and drought as major changes affecting agriculture. Moreover, according to those researchers, higher water levels are occurring in inland valleys during rainy seasons. Dansi et al. (2013) report an increased trend in rainfall in the department of Atacora over the period 1971-2010. Similarly, Allé et al. (2013) signal in the periods 1971-1990 and 1991-2010, a relative rise of the seasonal total rainfall over the 2 rainy seasons $(7 \%$ and $17 \%)$ on the plain of Allada in southern Benin. Resulting from climate change, extreme rainfall events as well as frequent floods represent a major concern in Benin 
since 1980 and seriously threaten the fulfillment of the Millennium Development Goals (Bénin \& PNUD, 2008). The country has experienced 40 natural disasters from 1980 to 2010, 14 of which were floods (OFDA/CRED, 2011). According to the same source, in the top 10 of the major natural disasters in terms of affected persons, 9 are flood events. For instance, in August 2010, extreme rainfall (in terms of volume, intensity and frequency) resulted in a rise of the levels of rivers Ouémé and Niger during 8 months (Bénin, BM, \& ONU, 2011). Agriculture which is the main source of livelihood for rural dwellers was the most affected. Indeed, approximately 50764 ha of lands under cultivation were destroyed. Besides, damages and losses were valued to 26.7 billion francs CFA. The same year, figures published by the Office for the Coordination of Humanitarian Affairs (OCHA) indicated that Benin was the country most impacted by the floods which occurred in West Africa in 2010. Indeed, Benin has experienced the highest number of victims that is 360000 affected persons and 43 casualties (OCHA, 2010). In 2012, floods stroke in the department of Borgou affecting 49321 persons and killing 10 others. Damages involved 24738 ha of food crop plots (ONU, 2012).

These alarming figures justify the need and urgency of studies permitting to predict the occurrences of floods. That is the framework in which stands our research entitled: Flood hazard assessment in agricultural areas: the case of the district of Pélébina in the municipality of Djougou.

This study tackles 2 research questions: Is there a high flood hazard in the locality of Pélébina? Is it possible to simulate the discharge generated in the channel of the inland valley of Dosir?

\section{Material and Method}

This study was conducted in the inland valley of Dosir located in the village of Pelebina in the district of Pelebina, municipality of Djougou in northern Benin (Figure 1). The inland valley is located in the catchment of Térou which is a sub-catchment of Donga. It covers an area of 49.45 ha. 


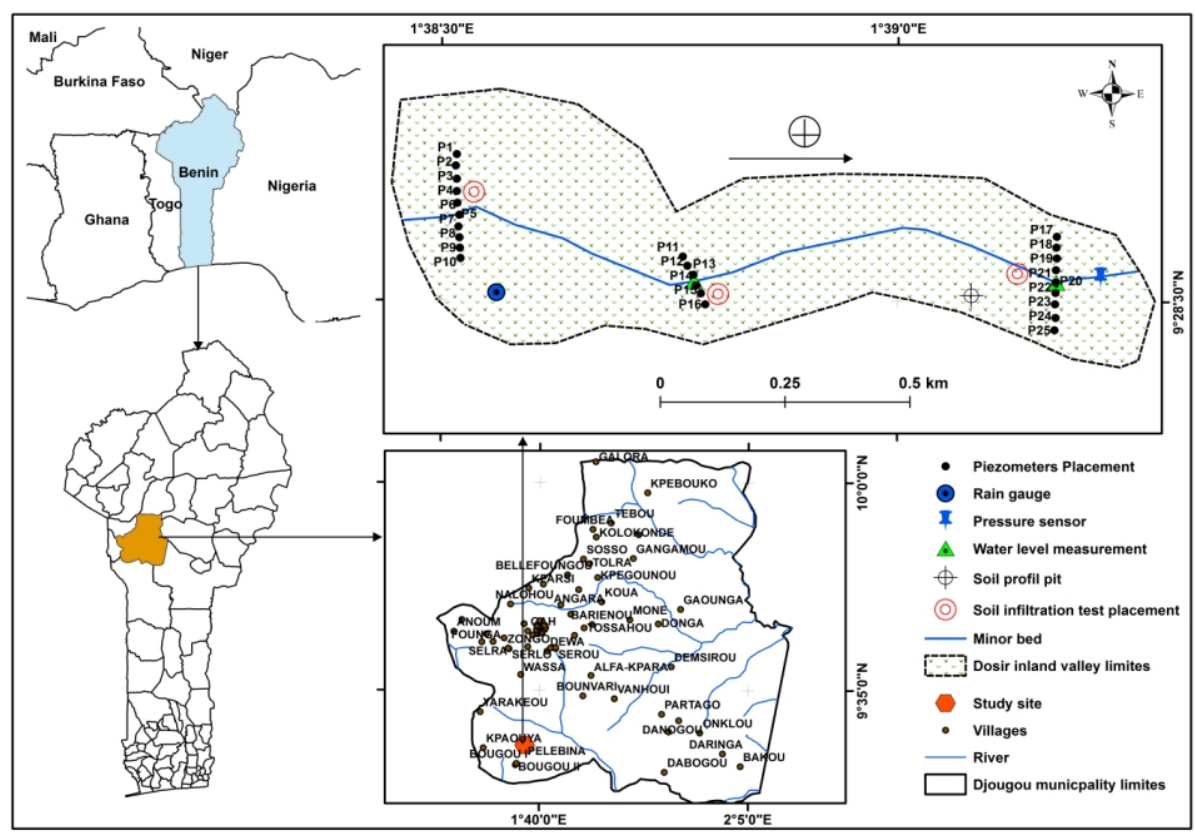

Figure 1: Location of the inland valley of Dosir in the district of Pélébina

\section{Data collection}

Rainfall, discharge and water level in the riverbed were monitored in the inland valley of Dosir. A rain gauge installed on the slope permitted to collect daily rainfall. Discharge was assessed downstream in the riverbed using an acoustic current meter. The water head was measured downstream in the riverbed with a datalogger. The data collection design is presented in figure 2.

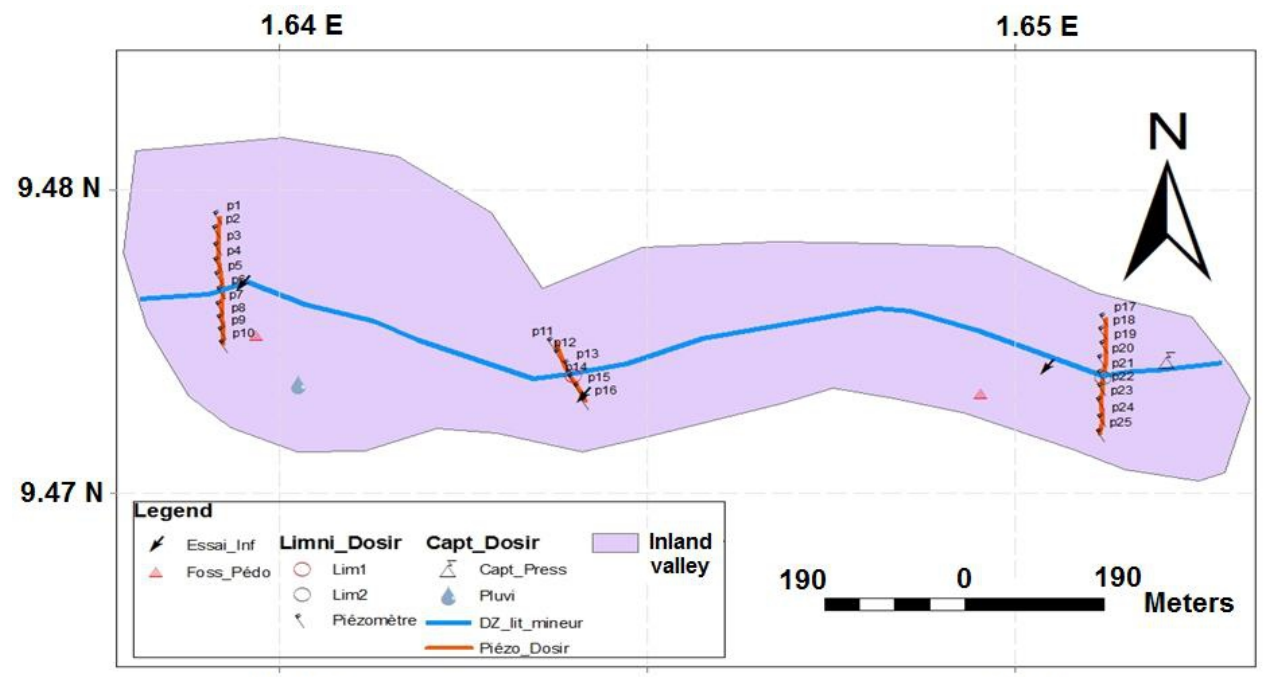

$1.64 \mathrm{E}$

$1.65 \mathrm{E}$

Figure 2: Data collection design on the inland valley of Dosir. 


\section{Data processing}

Rainfall data was processed with the Excel spreadsheet for the design of charts. The program HYDRACCESS developed by the French research center (Institut de Recherche pour le Développement (IRD) was used for processing discharge measurements and establishing the rating curve for the riverbed of the inland valley. The rainfall-runoff model IFAS version 1.2 was used to simulate runoff in the inland valley.

\section{Integrated Flood Analysis Model}

IFAS is a brief flood analysis toolkit designed by the International Centre for Water Hazard and Risk Management (ICHARM). It permits to simulate runoff and presents the advantage of accommodating to poorly gauged catchments. Thus, it is suitable for hydrological studies in developing countries like Benin where hydrometric stations are very limited. Indeed, this model provides the flood height and flow rate at the outlet of a river using ground rainfall or satellite measurements as input. In this study, we tested the ability of the IFAS to reproduce the discharge at a reduced scale of an inland valley.

\section{Input data}

Our study area is located between $9^{\circ} 27^{\prime} 20^{\prime \prime}$ ' and $9^{\circ} 29^{\prime} 50^{\prime \prime}$ ' of North latitude; $1^{\circ} 37^{\prime}$ and $1^{\circ} 40^{\prime}$ of East longitude. The time scale is 24 hours on the period from 8 August 2013 at 12 AM to 28 November 2013 at 11 PM. The resolution has been tuned to its maximum value which is $100 \mathrm{~m}$. Rainfall data collection covered the period from 8 August 2013 to 17 October 2013. Elevation data from Hydro1k DEM provided by USGS was used to create runoff. Rainfall values read daily by an operator were then computed as a csv file. This data has been regionalized to the whole catchment using the kriging option of IFAS. Land cover is derived from the GlobalMap data set. All input data are summarized in table 1.

Table 1: Input data

\begin{tabular}{ccc}
\hline Data & Type & Source \\
\hline Hydro1k & Digital Elevation & http://edcftp.cr.usgs.gov/pub/data/gtopo3 \\
Model & Ohydro/ \\
GlobalMap & Land cover & http://211.19.49.27/cgi-bin/gm_gl/ \\
(Landcover) & Soil water & Bouwman et $\begin{array}{c}\text { al..(1993) and analysis on } \\
\text { soil samples }\end{array}$ \\
$\begin{array}{c}\text { Soil Water Holding } \\
\text { Capacity }\end{array}$ & & \\
\hline
\end{tabular}

\section{Parameters setting}

The setting of the parameters of the model followed 3 steps: surface parameters setting, aquifer parameters setting and river channel parameters. A first default setting is implemented by IFAS based on the inputs data. 


\section{$\checkmark$ Surface parameters}

Surface parameters are mainly composed of roughness coefficient and final infiltration rate. The list of surface parameters is provided in table 2 .

Table 2: Surface parameters

\begin{tabular}{cccc}
\hline Parameters & Symbol & Notation & Unit \\
\hline Final infiltration capacity & $\mathrm{f}_{0}$ & SKF & $\mathrm{cm} / \mathrm{s}$ \\
Maximum storage height & $\mathrm{S}_{\mathrm{f} 2}$ & HFMXD & $\mathrm{m}$ \\
Height where occurs & $\mathrm{S}_{\mathrm{f} 1}$ & HFMND & $\mathrm{m}$ \\
Rapid intermediate flow & & & \\
Height where occurs ground infiltration & $\mathrm{S}_{\mathrm{f} 0}$ & HFOD & $\mathrm{m}$ \\
Surface roughness coefficient & $\mathrm{N}$ & SNF & $\mathrm{m}^{-1 / 3} / \mathrm{s}$ \\
Rapid intermediate flow regulation coefficient & $\alpha_{\mathrm{n}}$ & FALFX & Non dimensional \\
Initial storage height & - & HIFD & $\mathrm{m}$ \\
\hline
\end{tabular}

Source : Fukami et al. (2009)

\section{$\checkmark$ Aquifer parameters}

Table 3 presents aquifer and river channel parameters. Table 3: Aquifer and river channel parameters

\begin{tabular}{cccc}
\hline Parameters & Symbol & Notation & Unit \\
\hline Slow intermediate flow regulation coefficient & $\mathrm{Au}$ & $\mathrm{AUD}$ & $(1 / \mathrm{mm}$ \\
Base flow coefficient & & & $/$ day $) 1 / 2$ \\
Storage height where the slow intermediate flow occurs & $\mathrm{Ag}$ & AGD & $1 /$ day \\
Initial storage height & - & HCGD & $\mathrm{m}$ \\
Breadth of river channel & $\mathrm{B}$ & - & $\mathrm{m}$ \\
Manning's roughness coefficient & $\mathrm{n}$ & $\mathrm{RNS}$ & $\mathrm{m}-1 / 3 / \mathrm{s}$ \\
Initial water table of river channel & - & RRID & $\mathrm{m}$ \\
\hline
\end{tabular}

Parameters' setting was performed by iteration on each parameter. Final values are summarized in table 4:

Tableau 4: Parameters set for the model

\begin{tabular}{|c|c|c|c|c|}
\hline Parameters & Notation & Unit & $\begin{array}{c}\text { Default } \\
\text { value }\end{array}$ & $\begin{array}{c}\text { Value } \\
\text { set }\end{array}$ \\
\hline Final infiltration capacity & SKF & $\mathrm{cm} / \mathrm{s}$ & $\begin{array}{c}0.000 \\
5\end{array}$ & 0.0585 \\
\hline Maximum storage height & HFMXD & $\mathrm{m}$ & 0.1 & 0.04 \\
\hline $\begin{array}{l}\text { Height where occurs } \\
\text { rapid intermediate flow }\end{array}$ & HFMND & $\mathrm{m}$ & 0.01 & 0.004 \\
\hline Height where occurs ground infiltration & HFOD & $\mathrm{m}$ & 0.005 & 0.0002 \\
\hline Surface roughness coefficient & SNF & $\mathrm{m}^{-1 / 3} / \mathrm{s}$ & 0.7 & 0.3 \\
\hline $\begin{array}{l}\text { Rapid intermediate flow regulation } \\
\text { coefficient }\end{array}$ & FALFX & $\begin{array}{c}\text { Non } \\
\text { dimensional }\end{array}$ & 0.8 & 0.8 \\
\hline Initial storage height & HIFD & $\mathrm{m}$ & 0 & 0 \\
\hline Slow intermediate flow regulation coefficient & AUD & $(1 \mathrm{~mm} / \mathrm{day})^{1 /}$ & 0.1 & 0.2 \\
\hline Base flow coefficient & AGD & 1/day & 0.003 & 0.003 \\
\hline $\begin{array}{c}\text { Storage height where the slow intermediate } \\
\text { flow occurs }\end{array}$ & HCGD & $\mathrm{m}$ & 2 & 2 \\
\hline
\end{tabular}




\begin{tabular}{|c|c|c|c|c|}
\hline Parameters & Notation & Unit & $\begin{array}{c}\text { Default } \\
\text { value }\end{array}$ & $\begin{array}{c}\text { Value } \\
\text { set }\end{array}$ \\
\hline Initial storage height & HIGD & $\overline{\mathrm{m}}$ & 2 & 2 \\
\hline Breadth of river channel & - & $\mathrm{m}$ & - & - \\
\hline Manning's roughness coefficient & RNS & $\mathrm{m}^{-1 / 3} / \mathrm{s}$ & 0.035 & 0.033 \\
\hline $\begin{array}{l}\text { Initial water table of } \\
\text { river channel }\end{array}$ & RRID & $\mathrm{m}$ & 0.2 & 0.2 \\
\hline
\end{tabular}

\section{Flood hazard determination}

\section{Frequency analysis of the yearly rainfall of Pélébina}

Annual rainfall data of Djougou have been considered for the period 1972-2002. The determination of descriptive statistics permitted to establish the mean rainfall and the standard deviation for that period (Eq.1). $\bar{x}=\frac{1}{n} \sum_{i=1}^{n} x_{i}$ and $\sigma=\frac{1}{n-1} \sum_{i=1}^{n}\left(x_{i}-\bar{x}\right)^{2}$

(Eq.1)

Then, we adjusted that time series to the normal distribution. Considering return periods of 10,20 and 100 years, exceedance probability $F_{d}$ and non-exceedance probability $F_{\text {nd }}$ were determined (Eq.2). $F_{d}=1 / T ; \mathrm{T}$ is the return period.

(Eq.2)

$$
F_{n d}=1-F_{d}
$$

The adjustment of the annual rainfall time series of Djougou to the normal distribution follows the equation Eq.3.

$X=m+u . \sigma$

(Eq.3)

$\mathrm{m}$ : mean of the sample, u: standardized normal variate and $\sigma$ : standard deviation

The parameter $\mathrm{u}$ is obtained from correspondence between the standardized normal variate and the exceedance probability.

From that correspondence, the values below are retained.

Tableau 5: Correspondence between the standardized normal variate and the exceedance probability.

\begin{tabular}{cccc}
\hline $\mathrm{T}$ & 10 & 20 & 100 \\
\hline $\mathrm{F}_{\text {nd }}$ & 0.99 & 0.95 & 0.90 \\
$\mathrm{U}$ & 1.28 & 1.64 & 2.33 \\
\hline
\end{tabular}

Source : Anctil et al. (2005)

On that basis, rainfall values with respective return periods of 10,20 and 100 years were calculated using equation 3 . 


\section{Determination of precipitation indexes}

Recommended in 2009 by the WMO, the Standardized Precipitation Index (SPI) is widely used to determine rainfall deficits at different time scales. It possesses the advantage of having good spatial coherence, allowing comparisons between areas with different climates. In this study, the SPI was computed using Eq. 4.

$$
S P I=\frac{\left(p_{i}-p_{m}\right)}{\sigma}
$$

$\mathbf{P i}$ is the precipitation of year $\mathrm{i}, \mathbf{P m}$ the average rainfall and $\boldsymbol{\sigma}$ the standard deviation of the series. We have used here the annual rainfall series of Djougou over the period from 1970 to 2002. This series meets the criteria formulated by WMO regarding the minimum length of the series to be used for the SPI which is 30 years. Calculated SPI values were then interpreted based on table 6 .

Table 6: Classification of SPI values

\begin{tabular}{cc}
\hline SPI class & Interpretation \\
\hline SPI $>2$ & Extreme Humidity \\
$1<\mathrm{SPI}<2$ & High Humidity \\
$0<\mathrm{SPI}<1$ & Moderate Humidity \\
$-1<\mathrm{SPI}<0$ & Moderate Drought \\
$-2<\mathrm{SPI}<-1$ & High Drought \\
$\mathrm{SPI}<-2$ & Extreme Drought \\
\hline
\end{tabular}

Source : Bergaoui and Alouini, 2001

\section{Estimation of hydrological risk}

As part of the protection of structures against flooding, particular attention is paid to the hydrological risk. The prevailing principle is to reduce the risk to an acceptable level while finding the best compromise possible with the available funding. Indeed, the more we want to reduce the risk, the more protection measures will be costly. Anctil et al. (2005) define the hydrological risk as the probability that a defined criterion is exceeded at least once during a period. The hydrological risk is defined by Anctil et al. (2005) with the following formula (Eq.5):

$R=1-\left(1-\frac{1}{T}\right)^{n} ; T$ is the return period and $\mathrm{n}$ le number of years considered. (Eq.5)

\section{Results and discussion \\ Flood hazard assessment}

The Standardized Precipitation Indexes are calculated for the period from 1970 to 2002 and presented in Tables 7, 8 and 9. The 1970s were characterized by high rainfall. This trend stopped in 1980 after a humidity peak in 1979. The early 1980s was marked by significant rainfall deficits as evidenced by the values of the Standardized Precipitation Index (Table 7). 
Table 7: Standardized Precipitation Indexes on the period from 1970 to 1980.

\begin{tabular}{|c|c|c|c|c|c|c|c|c|c|c|c|}
\hline Year & $\begin{array}{c}197 \\
0\end{array}$ & $\begin{array}{c}197 \\
1\end{array}$ & $\begin{array}{c}197 \\
2\end{array}$ & $\begin{array}{c}197 \\
3\end{array}$ & $\begin{array}{c}197 \\
4\end{array}$ & $\begin{array}{c}197 \\
5\end{array}$ & $\begin{array}{c}197 \\
6\end{array}$ & $\begin{array}{c}197 \\
7\end{array}$ & $\begin{array}{c}197 \\
8\end{array}$ & $\begin{array}{c}197 \\
9\end{array}$ & $\begin{array}{c}198 \\
0\end{array}$ \\
\hline SPI & 0.30 & 2.58 & 0.45 & $\begin{array}{c}- \\
0.02\end{array}$ & 0.13 & 0.54 & $\begin{array}{c}- \\
0.10\end{array}$ & $0 . \overline{25}$ & 0.59 & 1.14 & 0.18 \\
\hline $\begin{array}{c}\text { Degre } \\
\mathrm{e}\end{array}$ & $\mathrm{MH}$ & ED & $\mathrm{MH}$ & MD & $\mathrm{MH}$ & $\mathrm{MH}$ & MD & MD & $\mathrm{MH}$ & $\mathrm{HH}$ & $\mathrm{MH}$ \\
\hline
\end{tabular}

MH: moderate humidity; ED: extreme drought; MD: moderate drought; HF: high humidity.

From 1981 to 1987,6 dry years were identified including 2 of extreme drought. Similar observations are made by Dansi et al. (2013) in the neighboring department of Atacora. This author signaled 1982, 1983 and 1984 as drought years. Table 8 , however, reveals a more favorable rainfall in the late $1980 \mathrm{~s}$.

Table 8: Standardized Precipitation Indexes on the period from 1981 to 1994.

\begin{tabular}{cccccccccccc}
\hline Year & 198 & 198 & 198 & 198 & 198 & 198 & 198 & 198 & 198 & 199 & 199 \\
& 1 & 2 & 3 & 4 & 5 & 6 & 7 & 8 & 9 & 0 & 4 \\
\hline SPI & - & - & - & - & & - & - & & & - & \\
& 2.35 & 2.35 & 1.54 & 1.17 & 0.24 & 0.08 & 0.54 & 0.81 & 0.37 & 0.22 & 0.41 \\
Degre & ED & ED & HD & HD & MH & MD & MD & MH & MH & MD & MH \\
e & & & & & & & & & & & \\
\hline
\end{tabular}

HD: high drought

Table 9: Standardized Precipitation Indexes on the period from 1995 to 2002.

\begin{tabular}{ccccccccc}
\hline Year & 1995 & 1996 & 1997 & 1998 & 1999 & 2000 & 2001 & 2002 \\
\hline SPI & 1.77 & 0.10 & 0.22 & 0.52 & 0.70 & 0.34 & 0.02 & 0.09 \\
Degree & HH & MH & MH & MH & MH & MH & MH & MH \\
\hline
\end{tabular}

The succession of wet years is then maintained until 2002. This suggests a repeated occurrence of annual rainfall above the average of the 30 years (1972-2002). Thus, in the study area, rainfall variation permits us to distinguish 3 periods. This is confirmed by the results of Gnanglè et al. (2011) who came to the conclusion that the evolution of rainfall in the whole sudano guineean area does not follow a linear trend from 1960 to 2008. The existence of a risk of extreme rainfall is well illustrated by the results of the frequency analysis on rainfall. We obtained by adjusting the series to the normal distribution, $1581.05 \mathrm{~mm}, 1705.44 \mathrm{~mm}$ and $1943.85 \mathrm{~mm}$ rainfall for return periods of 10, 20 and 100 years, respectively. The decennial wet rain was exceeded in 1995 when a rainfall of $1775.2 \mathrm{~mm}$ was recorded. This confirms the high value obtained after the calculation of the hydrological risk over 30 years. Indeed, it indicated a probability of 0.96 for the decennial rainfall to be exceeded each year. Furthermore, these observations are in accordance with farmers who reported having suffered from the consequences of heavy rainfall in the last 20 years. 


\section{Modelling}

The operation of IFAS according to the parameters discussed in the methodology permits to simulate runoff on the inland valley. The simulated discharge in the riverbed is presented in figure 3. An analysis of the period from 21 September to 4 October 2013 gives an idea of the speed of the inland valley's response to rainfall events. The reaction of the hydrogram in consequence of the rain on 21 September 2013 intervened just after a few hours.

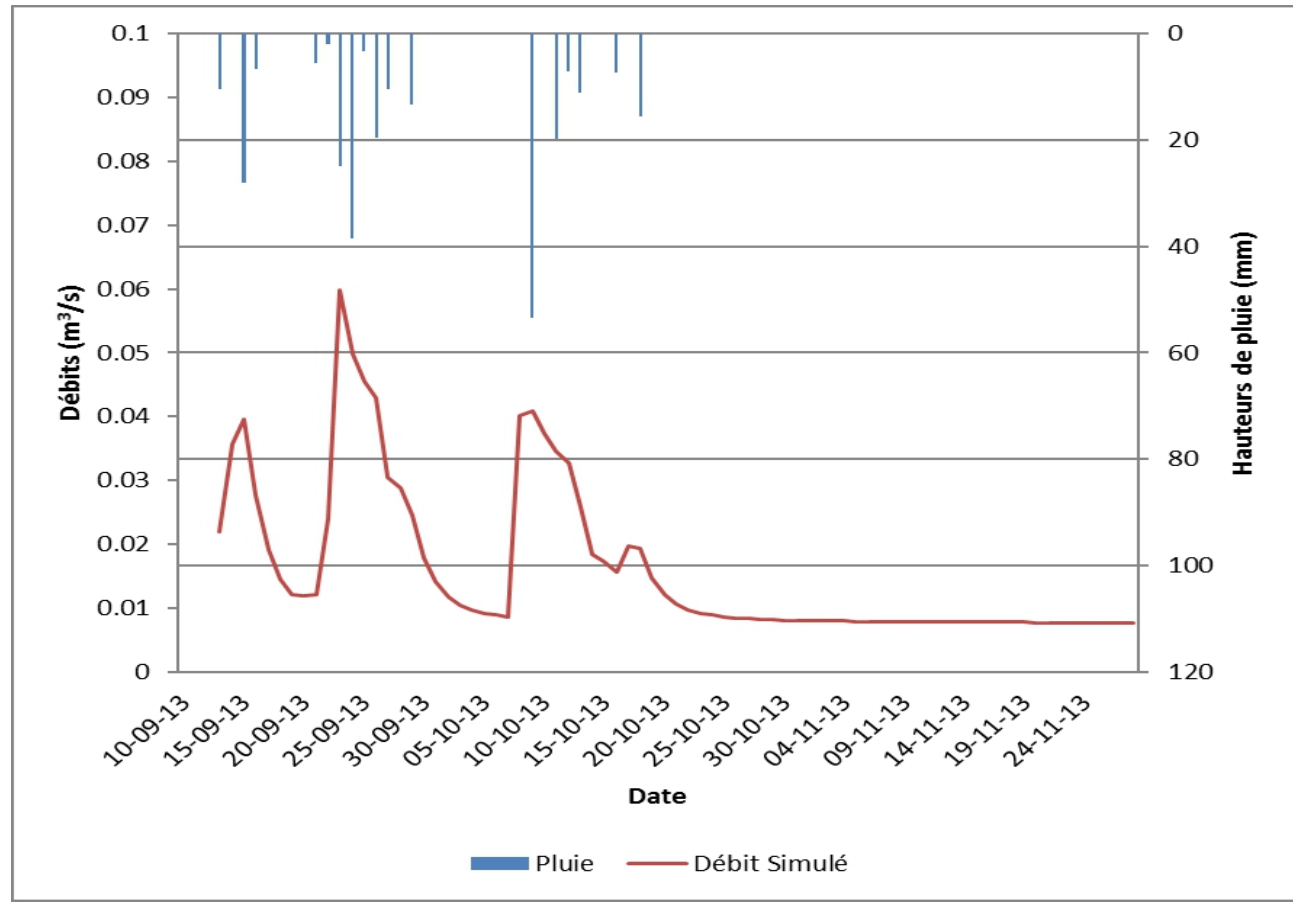

Figure 3: Simulated discharge

To assess the capacity of the model to simulate runoff in the inland valley of Dosir, simulated discharge was compared to measured discharge. As shown in figure 3 , the peaks in the discharge simulated by IFAS (green line) are well synchronized with the peaks in the observed discharge (red line). The regression analysis revealed a coefficient of determination $R^{2}=0.65$, the regression equation being $\mathrm{y}=0.9289 \mathrm{x}+0.0067$. This means that the model explains $65 \%$ of the variability in observed discharge. Nonetheless only dispersion is quantified in $\mathrm{R}^{2}$ as mentioned by Krause et al. (2005). This author suggests that the use of the gradient $b$ and the intercept $a$ of the regression alongside the coefficient of determination conveys more information. The value of the intercept (0.0067) is close to zero and the gradient b is close to 1 . According to Krause et al. (2005), this means an observed runoff of zero will also be associated to a value of simulated runoff near zero. 


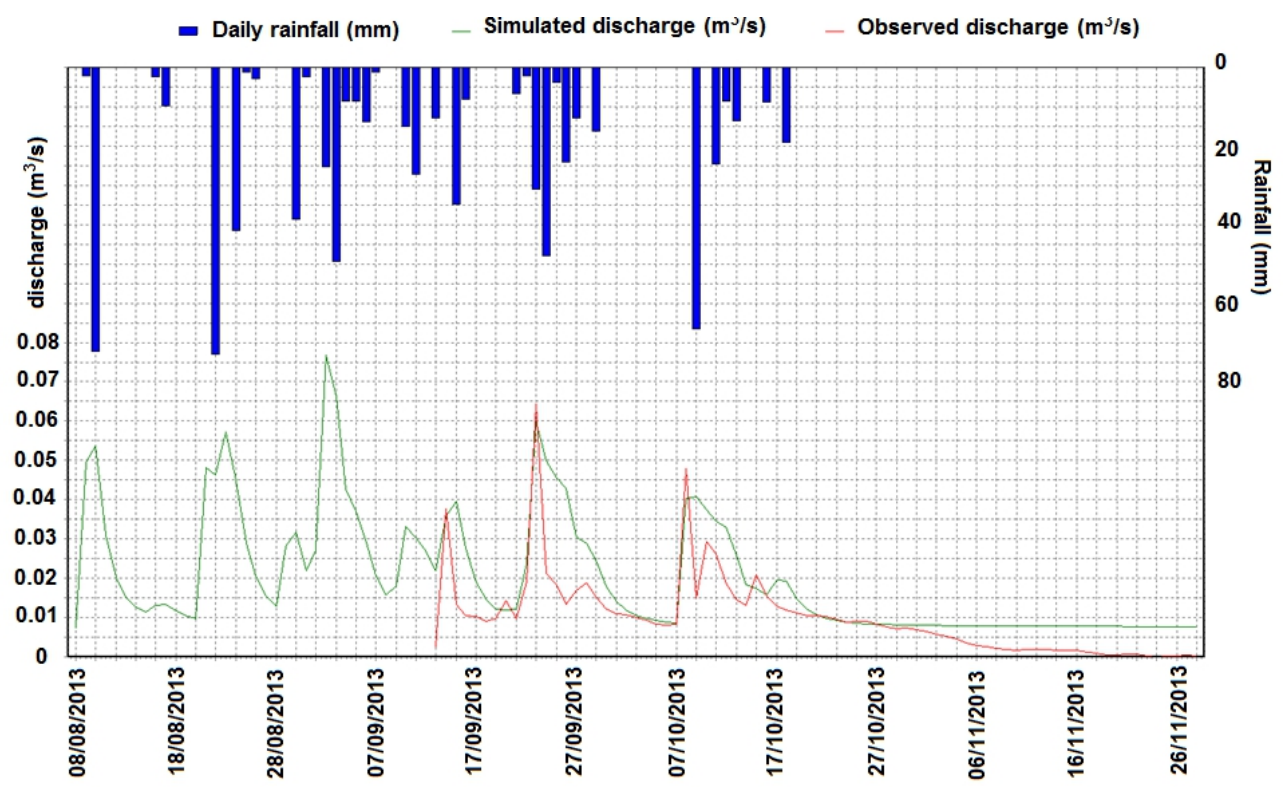

Figure 3: Simulated discharge compared to measured discharge

\section{Conclusion}

Our study demonstrates the existence of a high flood hazard in the study area. The IFAS model has shown a good performance in simulating runoff on the inland valley of Dosir. The calculated coefficient of determination is 0.65 . It stands out that the inland valley of Dosir reacts very quickly to rainfall solicitations. Nonetheless, longer time series of observations are needed to calibrate and validate the model. Besides, implementing the analysis at the scale of the whole catchment will provide a deeper understanding of flood generation processes. Then, the model could be used to design a flood management system for farmers of the sub-catchment of Térou. Moreover, socioeconomic aspects are needed to assess the exposure and vulnerability of farmers and hence establish their flood risk.

\section{References:}

1. Adams, W. M. (1993). Indigenous use of wetlands and sustainable development in West-Africa. Geographical journal, 159, 209-218.

2. Africa Rice Center. (2010). Réalisation du potentiel agricole des zones des bas-fonds en Afrique subsaharienne tout en maintenant leurs services environnementaux (projet RAP). Rapport de l'atelier final de la phase 1 (2009-2010) du projet RAP, (pp. 1-72). Cotonou, Benin.

3. Agossou, D. S., Tossou, C. R., Vissoh, V. P., \& Agbossou, K. E. (2012). Perceptions des perturbations climatiques, savoirs locaux et stratégies d'adaptation des producteurs agricoles au Bénin. African Crop Science Journal, 20(2), 565-588. 
4. Allé, U. C., Vissin, E. W., Vissoh, P. V., Guibert, H., Agbossou, E. K., \& Afouda, A. (s.d.). Perceptions paysannes de la variabilité climatique entre 1951 et 2010 au Sud du Bénin. XXVIème colloque de l'Association Internationale de Climatologie , (pp. 57-62).

5. Anctil, F., Rousselle, J., \& Lauzon, N. (2005). Hydrologie: cheminements de l'eau. Québec: Presses internationales polytechnique.

6. Bénin, \& PNUD. (2011). Programme d'Action National d'Adaptation aux changements climatiques du Bénin (PANA-Benin). Cotonou: Ministère de l'Environnement et de la Protection de la Nature.

7. Bénin; BM; ONU. (2011). Inondations au Bénin, Rapport d'évaluation des Besoins Post Catastrophes. Cotonou.

8. Bergaoui, M. \& Alouini, A., (2001). Caractérisation de la sécheresse météorologique et hydrologique : cas du bassin versant de Siliana en Tunisie. Sécheresse, 12(4), 205-213.

9. Dansi, A., Loko, Y. L., Agré, A. P., Akpa, N., Dossou-Aminon, I., Assogba, P., . . . Sanni, A. (2013, Avril). Perceptions paysannes et impacts des changements climatiques sur la production et la diversité variétale de l'igname dans la zone aride du nord-ouest du Bénin. International Journal of Biological and Chemical Sciences, 7(2), 672695. Récupéré sur http://ajol.info/index.php/ijbcs

10. Dembélé, Y. (2010). Intérêt du développment des bas-fonds en Afrique de l'Ouest: Implication des bénéficiaires et inventaire du potentiel. 1.

11. EM-DAT: The OFDA/CRED International Disaster Database. (2011, August). Brussels: Université catholique de Louvain.

12. Erenstein, O. (2006). Drivers and modifiers of lowland use in West Africa. Paper prepared for presentation at the International Association of Agricultural Economists Conference. paper prepared for presentation at the International Association of Agricultural Economists Conference, (p. 15).

13. Fukami, K., Y. Sugiura, J. Magome, and T. Kawakami, (2009). Integrated Flood Analysis System (IFAS Ver. 1.2), User's Manual. Japan PWRI-technical note, No.4148, 223 pp.

14. Gnanglè, C. P., Glèlè-Kakai, R., Assogbadjo, A. E., Vodounnon, S., Yabi, J. A., \& Sokpon, N. (2011). Tendances climatiques passées, modélisation, perceptions et adaptations locales au Bénin. Climatologie, 8, 27-40.

15. Judex, M., Röhrig, J., Schulz, O., \& Thamm, H.-P. (2009). IMPETUS Atlas du Bénin. Résultats de recherche 2000-2007. (éd. 3ème). (U. d. Département de Géographie, Éd.) Allemagne: Université de Bonn. 
16. Krause, P., Boyle, D. P., \& Base, F. (2005). Comparison of different efficiency criteria for hydrological model assessment. European Geosciences Union (EGU), 89-97.

17. Nicholls, R. J. (1995). Coastal megacities and climate change. Geojournal, 37(3), 369-379.

18. OCHA. (2010). Inondations 2010, Bulletin d'information $\mathrm{N}^{\circ} 2$. Bureau Régional pour l'Afrique de l'Ouest et du Centre, Sénégal.

19. ONU. (2012). Compte-rendu de l'évaluation rapide conjointe de la situation des inondations dans les départements du Borgou et de l'Alibori. Cotonou, Bénin.

20. SWAC/OCDE. (2013, May 2). Smart. Consulté le February 21, 2014, sur OCDE: http://westafricagateway.org/smart/

21. Windmeijer, P.N. \& Andriesse, W. (1993). Inland Valleys in West Africa: An Agro-ecological Characterization of Rice-Growing Environments. ILRI Publication 52. International Institute for Land Reclamation and Improvement, Wageningen, The Netherlands. 160 p. 